\title{
Application of multivariate statistics towards the geochemical evaluation of fluoride enrichment in groundwater at Shilabati river bank, West Bengal, India
}

\author{
Arghya Ghosh, Sandip Mondal ${ }^{\dagger}$ \\ Department of Earth and Environmental Studies, National Institute of Technology Durgapur, Mahatma Gandhi Avenue, Durgapur, State: West Bengal, \\ Pin-713209, India
}

\begin{abstract}
To obtain insightful knowledge of geochemical process controlling fluoride enrichment in groundwater of the villages near Shilabati river bank, West Bengal, India, multivariate statistical techniques were applied to a subgroup of the dataset generated from major ion analysis of groundwater samples. Water quality analysis of major ion chemistry revealed elevated levels of fluoride concentration in groundwater. Factor analysis (FA) of fifteen hydrochemical parameters demonstrated that fluoride occurrence was due to the weathering and dissolution of fluoride-bearing minerals in the aquifer. A strong positive loading $(>0.75)$ of fluoride with $\mathrm{pH}$ and bicarbonate for FA indicates an alkaline dominated environment responsible for leaching of fluoride from the source material. Mineralogical analysis of soli sediment exhibits the presence of fluoride-bearing minerals in underground geology. Hierarchical cluster analysis (HCA) was carried out to isolate the sampling sites according to groundwater quality. With HCA the sampling sites were isolated into three clusters. The occurrence of abundant fluoride in the higher elevated area of the observed three different clusters revealed that there was more contact opportunity of recharging water with the minerals present in the aquifer during infiltration through the vadose zone.
\end{abstract}

Keywords: Factor analysis, Fluoride, Groundwater, Hierarchical cluster analysis

\section{Introduction}

There is no existence of life on the earth without water. Groundwater is the most valuable source of water for various purposes and indispensable because of its inherent value. But increased urbanization and agricultural expansions result in overexploitation of groundwater resources in an unsustainable declining trend [1]. The major problem with groundwater is that once contaminated, it is very much difficult to restore its quality again [2]. The quality of groundwater in an area is mainly influenced by natural processes as well as anthropogenic activities [3]. Groundwater fluoride enrichment is one of such process which is associated with natural phenomena such as prolonged water-rock interaction, weathering and leaching of fluoride-bearing minerals or due to anthropogenic activities such as the excess application of pesticides and phosphatic fertilizers in the agricul- tural field, industrial activity such as aluminium smelting [4, 5]. Potential sources of fluoride in groundwater incorporate different minerals present in rocks and soils for example fluorite, apatite, micas, muscovite, amphiboles which are ordinarily found in gneiss terrane [6]. Groundwater chemistry enhancing the fluoride concentration includes $\mathrm{pH}$, the concentration of $\mathrm{HCO}_{3}{ }^{-}, \mathrm{Ca}^{2+}$ and $\mathrm{Na}^{+}$ions [7]. Other than groundwater chemistry the elevated evapotranspiration in the arid and semi-arid region also accelerate the fluoride concentration in groundwater [8].

Fluoride has both positive and negative health impacts on the human body when it is consumed by drinking water. Daily ingestion of about $1 \mathrm{mg} / \mathrm{L}$ of fluoride in drinking water is beneficial for mineralization of bone and formation of enamel to reduce the incidence of dental caries [9, 10]. Consumption of excess fluoride for a prolonged period causes incurable crippling of dental and skeletal fluorosis and additionally another detrimental health effect like retardation of normal growth, mobility loss, DNA struc-

Received May 21, 2018 Accepted July 31, 2018

${ }^{\dagger}$ Corresponding author

Email: san.mondal@gmail.com

Tel: +91-9434789021

ORCID: 0000-0001-9871-2011

Copyright (C) 2019 Korean Society of Environmental Engineers 
ture change and even death when reaches to abnormal dose (about $250 \mathrm{mg} / \mathrm{L})[11,12]$.

It has been reported that more than 200 million people around the world are under the threat of fluorosis (Disease caused by excess intake of fluoride) due to the intake of drinking water containing fluoride concentration which exceeds the present WHO permissible limit of $1.5 \mathrm{mg} / \mathrm{L}[10,13]$. In India 20 states are under the threat of endemic fluorosis which includes $65 \%$ of the rural population [14]. Taking into account the expanding reports on fluoride contamination in groundwater a Rapid Assessment Survey was conducted by the Fluoride Task Force, Govt. of West Bengal. From the survey, it was finally found that predominance of elevated fluoride concentration in 43 blocks of 7 districts namely Bankura, Birbhum, Purulia, Malda, South 24-Parganas, North and South Dinajpur [15]. The present study has been conducted in the villages near Shilabati river bank of Bankura district where groundwater is the only source for drinking as well as irrigation purpose. From the socio-economic point of view, the study area is backward. Due to less availability of fresh drinking water and unavailability of centralized drinking water treatment facility people compelled to take fluoride contaminated water for drinking purpose.

The application multivariate statistical techniques, such as factor analysis (FA), cluster analysis helps to consolidate a large number of original data with great efficiency so that they can be readily interpreted to obtain information of environmental geochemical origin, for the identification of the possible factors or sources influencing water quality and offers a valuable tool for water resource management [16, 17]. These techniques have been applied by several researchers to understand the dominant factors controlling fluoride geochemistry and also the spatiotemporal variation of fluoride in groundwater [18-20].

The primary objective of the present research work is to evaluate the characteristic of fluoride rich groundwater using FA for explaining the hydrogeochemical process of fluoride enrichment and also to delineate the spatial variation of fluoride in the study area using cluster analysis.

\section{Description of Study Area}

\subsection{Location and Hydrometeorology}

The study area that has been taken is a part of Silabati River Basin in Simlapal block of Bankura district of West Bengal State. It is geographically extended from $22^{\circ} 59^{\prime} 34^{\prime \prime}$ North to $22^{\circ} 54^{\prime} 37.00^{\prime \prime}$ North latitude and $86^{\circ} 58^{\prime} 51^{\prime \prime}$ East to $87^{\circ} 4^{\prime} 60^{\prime \prime}$ East longitudes. The entire study area is about $114 \mathrm{~km}^{2}$.

The climatic condition of the area under study is tropical with an average annual rainfall of $1,400 \mathrm{~mm}$. About $80 \%$ of the total precipitation is received during July to October. The maximum temperature reaches $46^{\circ} \mathrm{C}$ during summer and lowers to minimum $8^{\circ} \mathrm{C}$ during winter.

\subsection{Geology and Hydrology of the Study Area}

Geomorphologically Bankura district is divided into three parts. Hilly hard rock dominates the western part while the central

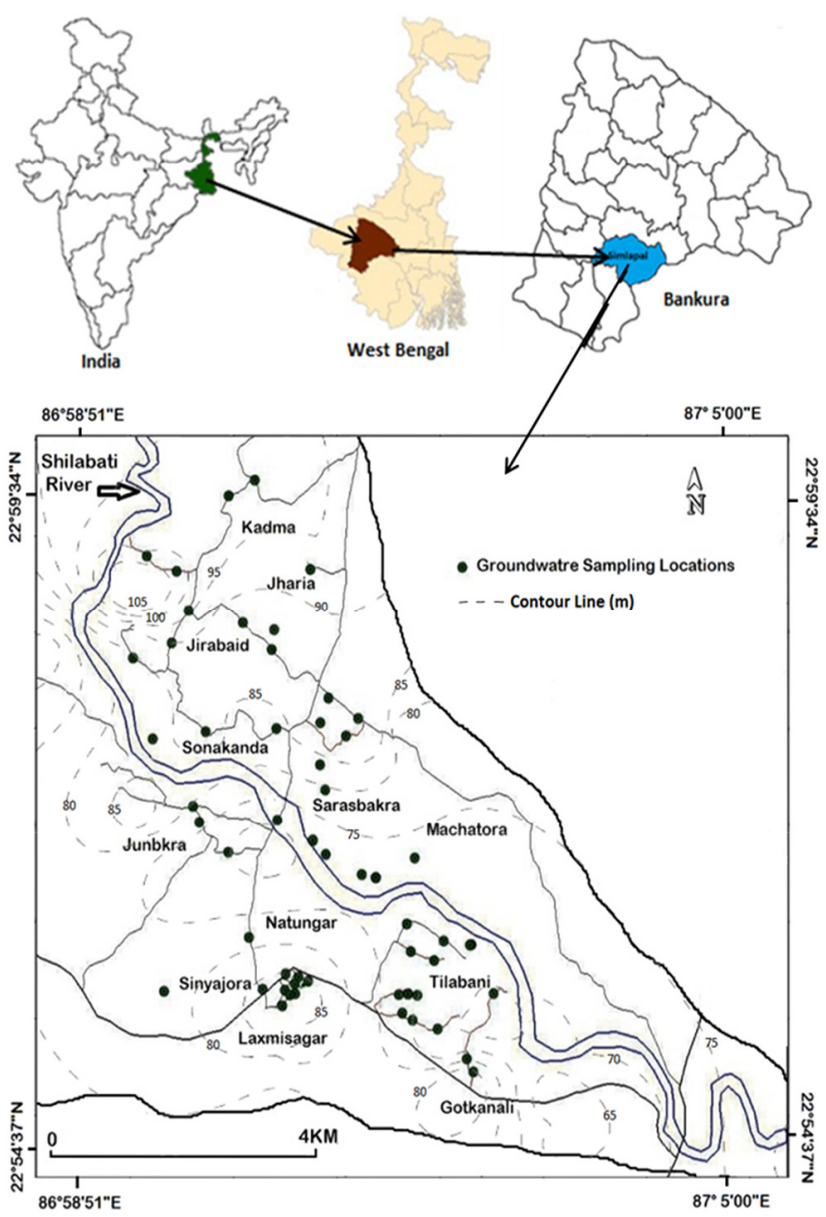

Fig. 1. Study area with groundwater sampling locations.

part is dominated by a mixed formation of both alluvial and rocky segments. The eastern part is a sedimentary alluvial plain, where the present study has been conducted. In this part, the water table lies between $1.5 \mathrm{~m}$ to $15 \mathrm{~m}$ below the ground level in the unconsolidated sandy sediments of recent alluvium which mostly contains laterite and fine loamy soil. The groundwater yield is good and used for agriculture with the help of shallow and deep tube wells.

\section{Materials and Methods}

\subsection{Sample Collection}

Groundwater samples were collected from 58 different location of the study area and the coordinates of sampling locations were noted by using a handled GPS set (Trimble Juno SA). To obtain a representative sample, the groundwater was collected after 5 min initiation of pumping procedure in two different set of sampling bottles, one $500 \mathrm{~mL}$ of the sample without any preservatives and one $250 \mathrm{~mL}$ of sample with $\mathrm{HCl}$ as a preservative for analysis of cations. For further chemical analysis collected samples were stored in an incubator at $4^{\circ} \mathrm{C}$. 


\subsection{Sample Analysis}

Onsite determination of $\mathrm{pH}$, Temperature, Total Dissolved Solids (TDS), Electrical Conductivity (EC) were conducted during sampling using a Multi-Parameter PCSTestr 35 (Eutech) and Oxidation and reduction potential using an ORPTestr 10 (Eutech). The major cations $\left(\mathrm{Mg}^{2+}, \mathrm{Ca}^{2+}, \mathrm{Na}^{+}, \mathrm{K}^{+}\right)$were analyzed using atomic absorption spectrometer (AAS, Perkin Elmer 900T) by following the standard method (EPA 7000B). The accuracy of the AAS results was confirmed by maintaining the $\mathrm{R}^{2}$ value of the calibration curve 0.99. The concentration of major anions $\left(\mathrm{SO}_{4}^{2-}, \mathrm{HCO}_{3}{ }^{-}, \mathrm{Cl}^{-}\right)$ was estimated by following standard test method [21]. As per the standard method sulphate $\left(\mathrm{SO}_{4}{ }^{2-}\right)$ was estimated by UV-Visible spectrophotometer (Shimadzu, UV1800) with the photometric accuracy of $\pm 0.002 \AA$. Titrimetric method was used to determine the alkalinity of unacidified samples. Chloride concentration was determined by argentometric method where relative standard deviation was maintained within $4.2 \%$ and a relative error of $1.7 \%$. Fluoride in the groundwater samples was determined potentiometrically using ion selective electrode (Orion 4 Star, Thermo scientific) by following the standard method (ASTM D 1179). This standard test method can be used to detect the fluoride concentration in water in between the concentration range of 0-19,990 ppm. Sodium fluoride (AR Grade, Merck) was used to prepare standard (0.1-10 mg/L) and stock solutions (100 mg/L). During analysis, the interference of other ions was restricted by adding a buffer solution (TISAB III, Orion) at 1:10 ratio of the samples. Before analysis, the fluoride meter was calibrated for a slope of $-59 \pm 2.0$.

\subsection{XRD Analysis}

The sediment samples collected from the most contaminated area were subjected to mineralogical analysis using X-ray diffractometry (XRD). Before analysis sediment samples were powdered and kept in a hot air oven for $24 \mathrm{~h}$ to expel the moisture content. To obtain a smooth and flat surface oven dried sample was placed into the sample holder. After that, the sample was inserted into the XRD machine to obtain the diffractograph of individual samples. The peak position and intensity of mineral structure were shown by the diffractogram. For identification of peak OriginPro 8 software was used. The peak of the diffractograph showed the presence of quartz, fluorite, and calcite in the soil sample (Fig. 2).

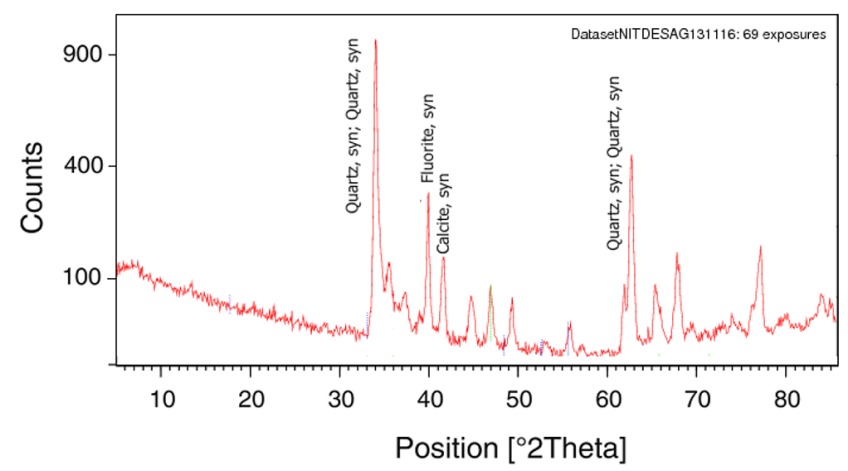

Fig. 2. Diffractogram showing the presence of quartz, fluorite, and calcite in soli sediment.

\subsection{Quality Assurance and Quality Control}

To maintain quality assurance and quality control analytical grade (Merck) chemicals were used for the standard preparation and also to conduct all desired experiments. To assure the quality of AAS result, a blank sample was run after 25 runs of samples to verify baseline stability. After analysis of every ten samples, the sensitivity of the instrument was verified using a known standard concentration to confirm the AAS reading. To cross-check the accuracy of major ion analysis, inorganic charge balance was conducted which was within $\pm 5 \%$ of the variance.

\section{Results and Discussion}

\subsection{General Hydrogeochemistry}

The physicochemical parameters along with descriptive statistics of collected groundwater samples are presented in Table 1. During extensive sampling, it was observed that $\mathrm{pH}$ of the groundwater sample varies in a wide range from 5.9 to 8.82 and 6.13 to 9.25 during pre- and post-monsoon, respectively, indicating slightly acidic to highly alkaline in nature. The higher $\mathrm{pH}$ in post-monsoon may be attributed to more carbonate dissolution. TDS varies from $73 \mathrm{mg} / \mathrm{L}$ to $790 \mathrm{mg} / \mathrm{L}$ and $60 \mathrm{mg} / \mathrm{L}$ to $1,330 \mathrm{mg} / \mathrm{L}$ during preand post-monsoon, respectively. Higher TDS during post-monsoon reveals more weathering and dissolution with the recharging rainfall water. The EC values were found to lie in the range of 126.8 to $1,240 \mu \mathrm{S} / \mathrm{cm}$ in the dry season and $5.02 \mu \mathrm{S} / \mathrm{cm}$ to 1,450 $\mu \mathrm{S} / \mathrm{cm}$ in the wet season. The higher standard deviation of TDS and EC values indicate the spatial variation of leaching and dissolution process in the study area. The oxidation and reduction potential (ORP) values were found to lie between $-70 \mathrm{mV}$ to 63 $\mathrm{mV}$ and $-133.11 \mathrm{mV}$ to $51.47 \mathrm{mV}$ during pre- and post-monsoon, respectively. The prevalence of oxidation and reducing conditions during pre- as well as post- monsoon indicate the existence of mixed type aquifer system in the study area. However, reduction conditions were predominant than oxidizing conditions. This could be due to predominance of alkaline ionized water along with the presence ferrous and sulphate ion that functioned as reducing agent in groundwater [22, 23]. The fluoride concentrations were varying from $0.25 \mathrm{mg} / \mathrm{L}$ to $17.81 \mathrm{mg} / \mathrm{L}$ and 0.08 $\mathrm{mg} / \mathrm{L}$ to $18.5 \mathrm{mg} / \mathrm{L}$ during pre- and post-monsoon, respectively. The sample with higher fluoride concentration was observed to have mostly negative ORP showing more tendencies to reduce the minerals present in the study area. It was also found that $\mathrm{Ca}^{2+}, \mathrm{Na}^{+}, \mathrm{Mg}^{2+}$ and $\mathrm{K}^{+}$were dominant cations and $\mathrm{HCO}_{3}{ }^{-}, \mathrm{Cl}^{-}$ and $\mathrm{SO}_{4}{ }^{2-}$ were major anions in the groundwater sample.

Using the major cations and anions, Piper trilinear diagrams were plotted for the classification of the groundwaters and the seasonal variations in hydrological facies [24]. From the diagram it was observed that majority of the groundwater samples plotted in the anion field contain $\mathrm{HCO}_{3}{ }^{-}$as major anion and the samples plotted in cation field contain $\mathrm{Na}^{+}, \mathrm{Ca}^{2+}$ as major cation. The analysis the central diamond field of piper plot suggested $\mathrm{Na}-\mathrm{Ca}-\mathrm{HCO}_{3}$ type of the groundwater for both the seasons. The high $\mathrm{HCO}_{3}{ }^{-}$type water in both the seasons indicate an alkaline environment is promoting the dissolution of $\mathrm{F}$ enriched minerals 
Table 1. Summery Statistic of Hydrochemical Parameters of the Groundwater Sample Collected from the Study Area

\begin{tabular}{|c|c|c|c|c|c|c|c|c|}
\hline \multirow{2}{*}{$\begin{array}{l}\text { Hydrochemical } \\
\text { parameters }\end{array}$} & \multicolumn{4}{|c|}{ Pre-monsoon } & \multicolumn{4}{|c|}{ Post-monsoon } \\
\hline & Minimum & Maximum & Mean & Std. deviation & Minimum & Maximum & Mean & Std. deviation \\
\hline $\mathrm{pH}$ & 5.9 & 8.82 & 6.98 & 0.47 & 6.13 & 9.25 & 7.04 & 0.46 \\
\hline TDS & 73 & 790 & 271.29 & 150.81 & 60 & 1,330 & 360.69 & 236.27 \\
\hline $\mathrm{EC}(\mu \mathrm{S} / \mathrm{cm})$ & 126.8 & 1,240 & 484.62 & 247.48 & 5.02 & 1,450 & 484.62 & 291.82 \\
\hline ORP (mV) & -70 & 63 & -15.16 & 31.7 & -133.11 & 51.47 & -2.43 & 27.35 \\
\hline $\mathrm{F}^{-}$ & 0.25 & 17.8 & 2.7 & 3.92 & 0.08 & 18.50 & 1.75 & 2.83 \\
\hline $\mathrm{Ca}^{2+}$ & 0.75 & 169.2 & 25.83 & 30.59 & 3.09 & 228.20 & 57.63 & 45.79 \\
\hline $\mathrm{Mg}^{2+}$ & 2.5 & 425 & 117.97 & 96.01 & 0.08 & 42.97 & 13.82 & 9.84 \\
\hline $\mathrm{Na}^{+}$ & 7.1 & 318.5 & 38.57 & 50.85 & 0.01 & 338.90 & 46.60 & 60.39 \\
\hline $\mathrm{K}^{+}$ & 0 & 31.2 & 3.82 & 7.41 & 0.01 & 99.16 & 7.42 & 16.61 \\
\hline $\mathrm{Cl}^{-}$ & 5 & 484.85 & 57.83 & 80.49 & 5 & 304.91 & 63.11 & 70.16 \\
\hline $\mathrm{SO}_{4}^{2-}$ & 0 & 55 & 11.49 & 11.4 & 0 & 55.00 & 12.51 & 11.62 \\
\hline $\mathrm{HCO}_{3}^{-}$ & 14.25 & 171 & 54.54 & 29.95 & 14.25 & 114.00 & 52.55 & 22.61 \\
\hline $\mathrm{Fe}$ & 0 & 10.7 & 1.3 & 1.69 & 0.01 & 16.47 & 2.93 & 3.41 \\
\hline $\mathrm{Ni}$ & 0 & 0.06 & 0.02 & 0.02 & 0 & 0.06 & 0.02 & 0.02 \\
\hline $\mathrm{Zn}$ & 0 & 4.29 & 0.34 & 0.91 & 0 & 3.90 & 0.30 & 0.82 \\
\hline
\end{tabular}

Note: All the units are expressed in mg/L except $\mathrm{pH}$, EC, and ORP.
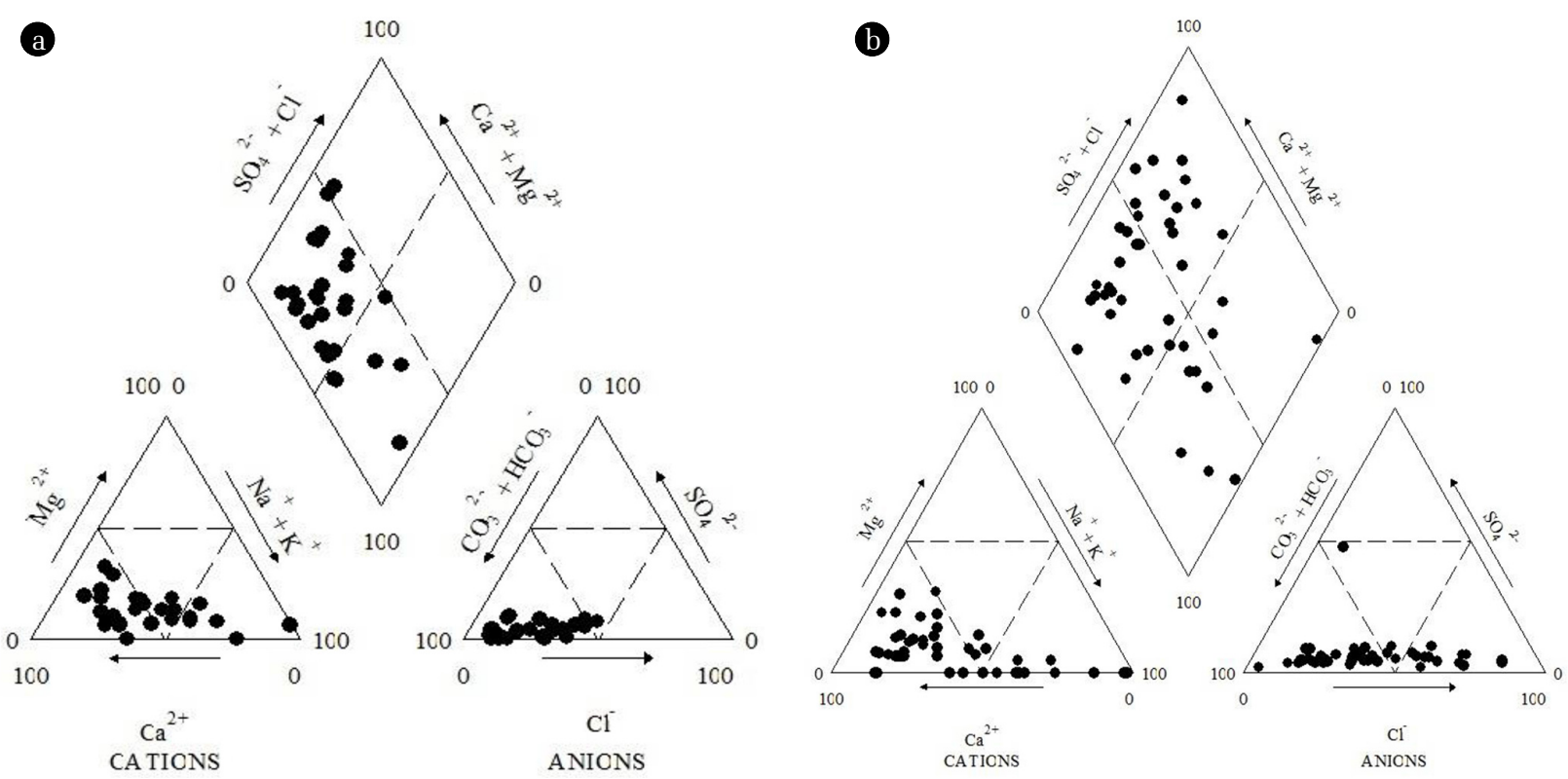

Fig. 3. Piper diagram of groundwater samples of the study area during pre-monsoon (a) and post-monsoon (b).

due to precipitation of calcite, under weaker fluorite solubility limit [25]. Piper plots also show the prevalent heterogeneity in groundwater quality which may be due to the presence of different aquifers at different depths or due to different geochemical processes influencing the groundwater chemistry in the study area.

To understand the controlling mechanism of the groundwater chemistry, Gibbs diagram was plotted to know the source of major ions. This diagram represents the ratio of $\left[\mathrm{Cl} /\left(\mathrm{Cl}+\mathrm{HCO}_{3}\right)\right]$ and
$[(\mathrm{Na}+\mathrm{K}) /(\mathrm{Na}+\mathrm{K}+\mathrm{Ca})]$ as a function of TDS for the assessment of working sources of dissolved ions in groundwater such as evaporation dominance, rock dominance and precipitation dominance [26].

Gibb's Ratio I (for anion) $=\mathrm{Cl} /\left(\mathrm{Cl}+\mathrm{HCO}_{3}\right)$

Gibb's Ratio II (for cation) $=\mathrm{Na}+\mathrm{K} /(\mathrm{Na}+\mathrm{K}+\mathrm{Ca})$

Gibb's Ratio I of groundwater samples ranges from 0.1 to 0.8 and whereas Gibb's Ratio II ranges from 0.2 to 0.9 for both the 

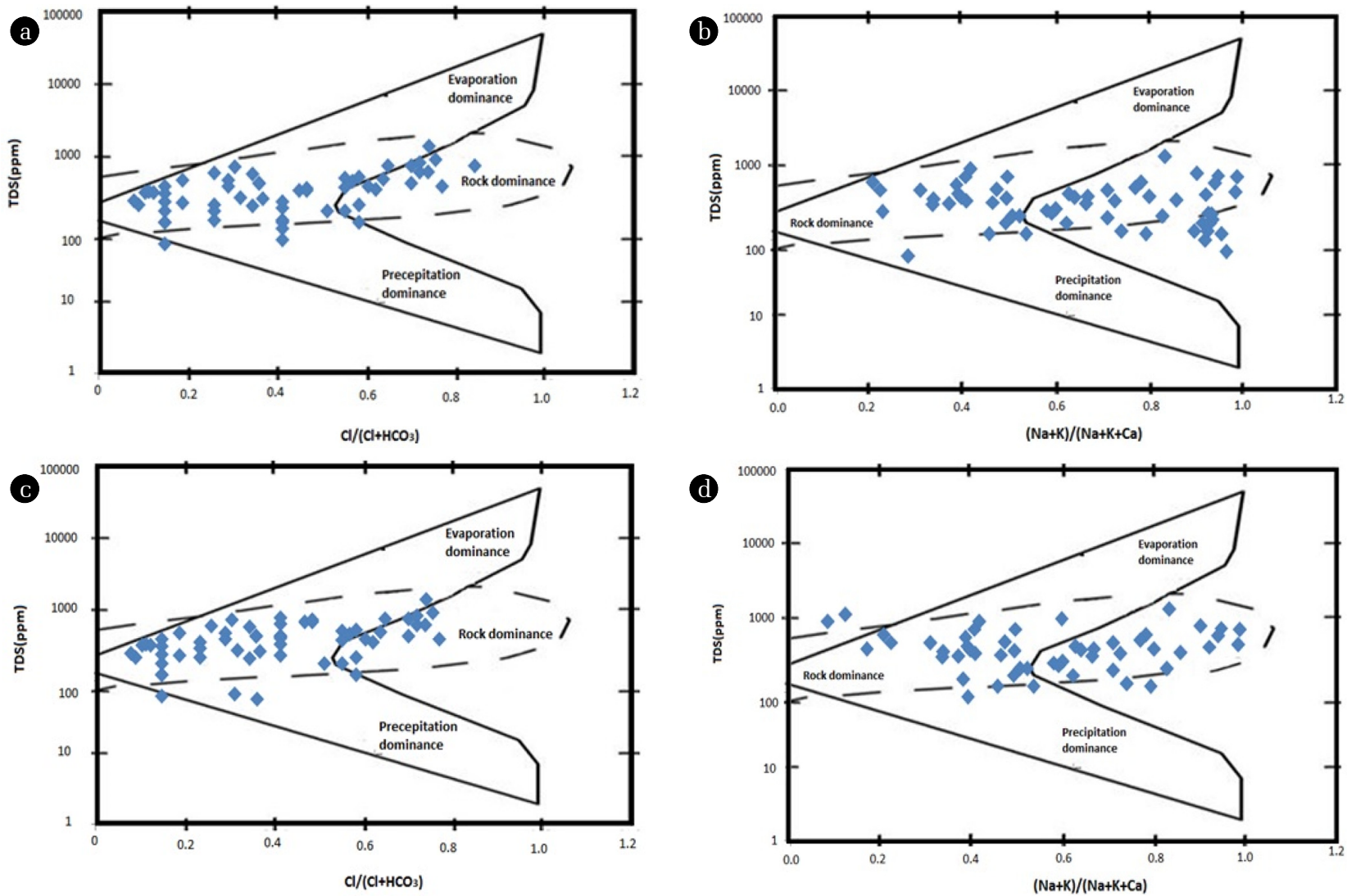

Fig. 4. Gibbs plot for anion and cation during pre-monsoon (a, b) and post-monsoon (c, d).

seasons, respectively. Gibbs plot demonstrates that rocks are the origin of major ions present in the groundwater samples. So, ions bearing minerals control the leaching mechanism.

\subsection{Factor Analysis}

FA was performed on fifteen physico-chemical parameters determined in 116 groundwater samples. The major components of the four principal factors which aggregately clarified $63.82 \%$ and $70.07 \%$ variation of the data during pre- and post-monsoon, respectively were deduced in Table 2. After completion of FA, an attempt was undertaken to interpret the principal factors. Factor loading greater than 0.75 considered as strong loading, factor loading between 0.75-0.5 considered as moderate loading while factor loading less than 0.5 as weak loading [27]. Varimax rotation technique was applied for a simple and easier interpretation where factors were arranged in decreasing order of importance [28]. The factor with the highest data variance commonly explains the most important process or blend of procedures which control the hydrochemistry [29].

During pre-monsoon, factor 1 accounted for $29.47 \%$ of the variance and having substantial loadings on $\mathrm{Na}^{+}, \mathrm{K}^{+}, \mathrm{SO}_{4}{ }^{2-}$, TDS, and EC. It represents the primary dissolved load of groundwater is due to dissolution of parent rocks like charnockites and gneisses as well as anthropogenic activities such as agriculture which influences the groundwater environment. The high loadings of
TDS and EC are strongly influenced by evaporative processes. Factor 2 which explains $14.24 \%$ of data variance was mainly influenced by $\mathrm{pH}, \mathrm{HCO}_{3}^{-}, \mathrm{F}^{-}$and ORP. Strong loadings for $\mathrm{F}^{-}$and $\mathrm{pH}$ ruminate an alkaline dominated environment which promotes the fluoride enrichment due to desorption of $\mathrm{F}^{-}$ions in aquifer materials thus supplementing the dissolution of fluoride-bearing minerals. Generally, the concentration of fluoride not depends upon water soluble components but a significant correlation exists between $\mathrm{pH}$ and $\mathrm{F}$. The solubility of fluoride is very low in the $\mathrm{pH}$ range of 5-6.5 [30]. But at higher $\mathrm{pH}$, the hydroxyl ion can supplant the replaceable $\mathrm{F}^{-}$ion of the fluoride-bearing minerals (biotite/muscovite) [31, 32]. Geochemically, $\mathrm{F}^{-}$and $\mathrm{OH}^{-}$ions have the same negative charge and possess nearly the same ionic radius, $1.33 \AA$ for $\mathrm{F}^{-}$and $1.40 \AA$ for $\mathrm{OH}^{-}[33,34]$. Therefore, facilitating the replacement of $\mathrm{OH}^{-}$and $\mathrm{F}^{-}$ions and thus enhancing the fluoride concentration of in groundwater. The hydroxyl ion supplants fluoride ion from muscovite and biotite is demonstrated as follows:

Muscovite

$$
\begin{gathered}
\mathrm{KAl}_{3} \mathrm{Si}_{3} \mathrm{O}_{10}(\mathrm{OH}, \mathrm{F})_{2}+\mathrm{CO}_{2}+2: 5 \mathrm{H}_{2} \mathrm{O} \rightarrow \\
1: 5 \mathrm{Al}_{2} \mathrm{Si}_{2} \mathrm{O}_{5}(\mathrm{OH})_{4}+\mathrm{K}^{+}+\mathrm{HCO}_{3}^{-}+2 \mathrm{~F}^{-}
\end{gathered}
$$

Biotite

$$
\begin{gathered}
\mathrm{KMg}_{3}\left[\mathrm{AlSi}_{3} \mathrm{O}_{10}\right] \mathrm{F}_{2}+2 \mathrm{OH}^{-} \rightarrow \\
\mathrm{KMg}\left[\mathrm{AlSi}_{3} \mathrm{O}_{10}\right] \mathrm{OH}_{2}+2 \mathrm{~F}^{-}
\end{gathered}
$$


The high positive loading for $\mathrm{HCO}_{3}{ }^{-}$also supports the fact that groundwater in the study area belongs to $\mathrm{HCO}_{3}{ }^{-}$type. Fluoride exists as a simple negative ion $(\mathrm{F})$ in $\mathrm{Na}-\mathrm{HCO}_{3}$ type groundwater which is highly active. Though fluoride combines with sodium to form water-soluble salt but the presence of sodium in groundwater decreases the sedimentation of calcium fluoride hence increases the fluoride concentration as below.

$$
\mathrm{CaF}_{2}+2 \mathrm{HCO}_{3}^{-} \rightarrow \mathrm{CaCO}_{3}+2 \mathrm{~F}^{-}+\mathrm{H}_{2} \mathrm{O}+\mathrm{CO}_{2}
$$

The interaction of groundwater with aquifer sediments containing fluorite $\left(\mathrm{CaF}_{2}\right)$ and calcite $\left(\mathrm{CaCO}_{3}\right)$ develops equilibrium reactions with both the solid phases by the following equations [35].

$$
\begin{gathered}
\mathrm{CaF}_{2} \rightarrow \mathrm{Ca}^{2+}+2 \mathrm{~F}^{-} \\
\mathrm{CaCO}_{3}+\mathrm{H}^{+} \rightarrow \mathrm{Ca}^{2+}+\mathrm{HCO}_{3}^{-}
\end{gathered}
$$

In order to relate fluorite and calcite when both the solute species are in contact with water the combined mass law equation can be explained by the Eq. (3) [35]. From these equations, it can be inferred that the change in $\mathrm{HCO}_{3}^{-}$will lead to a corresponding alteration in $\mathrm{F}^{-}$[35]. The $\mathrm{HCO}_{3}^{-}$acts as a sink for $\mathrm{Ca}^{2+}$ to form $\mathrm{CaCO}_{3}$ and thus makes favourable condition for the dissolution of $\mathrm{F}^{-}$from $\mathrm{CaF}_{2}$ into the groundwater [36].

On the other hand, negative loading of ORP indicates a reduction condition prevails in the aquifer which further enhances the enrichment process.
Factor 3 which represents $10.91 \%$ of the aggregate fluctuation in the hydrochemistry, shows positive loadings for $\mathrm{Ca}^{2+}, \mathrm{Mg}^{2+}$, and $\mathrm{Cl}^{-}$. This factor can likewise be named as the hardness factor. High loadings of $\mathrm{Ca}^{2+}$ and $\mathrm{Mg}^{2+}$ suggests weathering of carbonate minerals such as calcite and dolomite as the source of these two cations, particularly in recharge areas. The mobilization of $\mathrm{Cl}^{-}$ from anthropogenic sources such as fertilizer may account for its strong loading. The dominating procedures represented by Factor 4, reflects the similar origin of $\mathrm{Fe}, \mathrm{Ni}$, and $\mathrm{Zn}$ in groundwater. High loading of $\mathrm{Fe}$ also points to reductive hydrolytic processes in the aquifer of the study area.

During post-monsoon, Factor 1 explains $32.27 \%$ of total variance and contains high loadings on TDS, $\mathrm{EC}, \mathrm{Ca}^{2+}, \mathrm{Mg}^{2+}, \mathrm{K}^{+}$, $\mathrm{Cl}^{-}$, and $\mathrm{HCO}_{3}^{-}$. It once again represents the weathering of different minerals such as halite, dolomite, gypsum, etc. from the underlying geology. Factor 2 explains $26.64 \%$ of total variance and has strong positive loadings on $\mathrm{pH}, \mathrm{Na}^{+}$and $\mathrm{F}^{-}$and negative loading with ORP. High loading of $\mathrm{HCO}_{3}{ }^{-}$and $\mathrm{pH}$ reflects an alkaline dominated environment promoting the $\mathrm{F}$ enrichment due to the ion exchange process. Factor 3 explains 10\% of the total variance and has the significant positive weight of $\mathrm{SO}_{4}{ }^{2-}$ and $\mathrm{HCO}_{3}{ }^{-}$which suggests the weathering of carbonate, sulfide minerals. Factor 4 accounts for $8.7 \%$ of the total variance, contains high loadings for $\mathrm{Fe}, \mathrm{Ni}$, and $\mathrm{Zn}$ indicating the similar source of these metals in the groundwater.

Comparing the results of FA for two seasons significant differ-

\begin{tabular}{|c|c|c|c|c|c|c|c|c|}
\hline \multirow{2}{*}{ Variables } & \multicolumn{4}{|c|}{ Pre-monsoon } & \multicolumn{4}{|c|}{ Post-monsoon } \\
\hline & Factor 1 & Factor 2 & Factor 3 & Factor 4 & Factor 1 & Factor 2 & Factor 3 & Factor 4 \\
\hline $\mathrm{pH}$ & 0.10 & 0.75 & -0.02 & -0.20 & -0.03 & 0.96 & -0.12 & 0.11 \\
\hline TDS & 0.83 & 0.45 & 0.26 & 0.02 & 0.84 & 0.08 & -0.01 & 0.02 \\
\hline EC & 0.86 & 0.20 & 0.12 & 0.04 & 0.95 & 0.15 & -0.01 & 0.01 \\
\hline ORP & -0.21 & -0.75 & -0.13 & 0.32 & 0.01 & -0.96 & 0.12 & -0.11 \\
\hline $\mathrm{F}^{-}$ & 0.11 & 0.81 & -0.22 & 0.03 & 0.01 & 0.94 & 0.03 & -0.16 \\
\hline $\mathrm{Ca}^{2+}$ & 0.19 & -0.30 & 0.76 & -0.35 & 0.90 & -0.17 & 0.06 & 0.07 \\
\hline $\mathrm{Mg}^{2+}$ & -0.02 & -0.13 & 0.89 & 0.10 & 0.91 & -0.14 & 0.05 & 0.15 \\
\hline $\mathrm{Na}^{+}$ & 0.69 & 0.33 & -0.12 & 0.02 & 0.06 & 0.96 & -0.05 & -0.11 \\
\hline $\mathrm{K}^{+}$ & 0.75 & -0.01 & 0.08 & -0.34 & 0.66 & 0.05 & -0.25 & -0.06 \\
\hline $\mathrm{Cl}^{-}$ & 0.63 & -0.02 & 0.93 & 0.07 & 0.71 & 0.43 & 0.08 & -0.39 \\
\hline $\mathrm{SO}_{4}{ }^{2-}$ & 0.78 & 0.15 & 0.42 & 0.08 & 0.06 & -0.12 & 0.73 & 0.63 \\
\hline $\mathrm{HCO}_{3}^{-}$ & 0.60 & 0.81 & 0.27 & 0.62 & 0.97 & 0.11 & 0.69 & 0.29 \\
\hline $\mathrm{Fe}$ & -0.05 & -0.19 & -0.17 & 0.72 & -0.19 & -0.19 & -0.12 & 0.80 \\
\hline $\mathrm{Ni}$ & -0.10 & 0.18 & 0.11 & 0.76 & -0.01 & -0.25 & -0.29 & 0.79 \\
\hline $\mathrm{Zn}$ & 0.00 & 0.02 & -0.10 & 0.78 & 0.11 & 0.02 & 0.14 & 0.82 \\
\hline Eigen value & 4.42 & 2.14 & 1.64 & 1.38 & 4.84 & 3.99 & 1.50 & 1.31 \\
\hline Total variance (\%) & 29.47 & 14.24 & 10.91 & 9.20 & 32.27 & 26.64 & 10.01 & 8.70 \\
\hline Cumulative (\%) & 29.47 & 43.71 & 54.62 & 63.82 & 32.27 & 58.92 & 68.92 & 77.62 \\
\hline
\end{tabular}
ences in factor weight has been observed for $\mathrm{pH}, \mathrm{F}, \mathrm{Ca}^{2+}, \mathrm{Mg}^{2+}, \mathrm{Na}^{+}$

Table 2. Rotated Factor Pattern of Five Factors after Varimax Rotation

Note: Bold values are considered significant. 

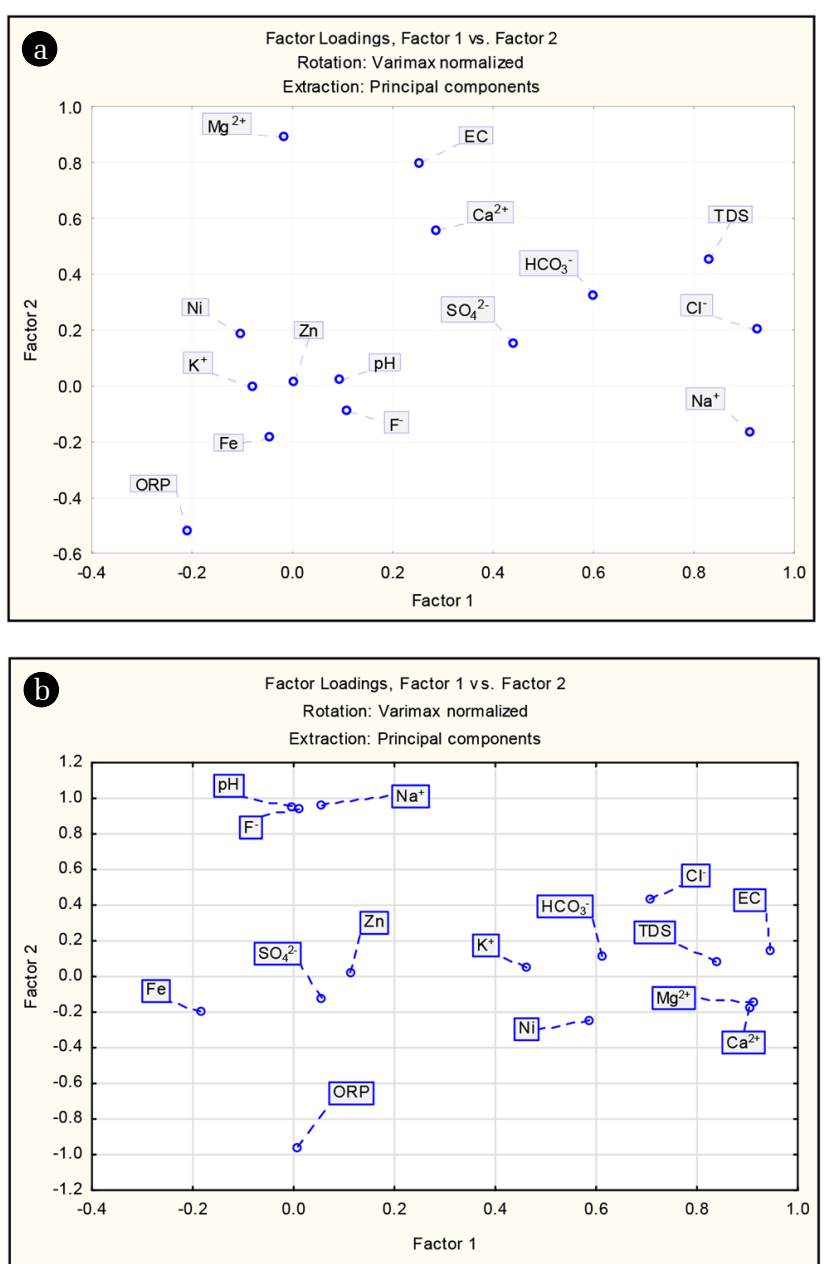

Fig. 5. Scatter plot of the factor loading between Factor 1 and Factor 2 during pre-nonsoon (a) and post-monsoon (b).

and $\mathrm{HCO}_{3}{ }^{-}$. The factor loadings were more during post-monsoon which revealed that recharging rainfall water enhanced the different hydro-geochemical processes such as weathering, dissolution, ion-exchange, etc. influencing the overall groundwater chemistry as well as fluoride enrichment in the study area. Finally, the result of FA for both the season provides better confidence in data interpretation.

First two factor loadings which explain $43.71 \%$ and $58.92 \%$ of total variance for pre- and post-monsoon respectively were plotted and illustrated in Fig. 5. These Scatter plots represent the possible relationship among the variables and their influence in the overall data structure. In order to comprehend the basic information structure in the present study and the significant factors based on the eigenvalue scree plot was also used as shown in Fig. S1.

\subsection{Clusters Analysis}

The hierarchical cluster analysis (HCA) was performed on fifteen geochemical parameters for an adequate partitioning of sampling sites based on the groundwater quality. In clustering Ward's meth- od was used as an amalgamation rule and Euclidean distance as dissimilarity measure. Finally, the result of the cluster analysis is shown in dendrogram or tree diagram. The dendrogram represents three statistically significant clusters of 58 sampling sites. The sites of an individual cluster represent similarity in the geochemical process as well as have a similar origin. Out of the three clusters, the first cluster consists of 27 sampling sites during pre-monsoon and 35 sampling sites during post-monsoon. The second cluster contains 23 sites during pre- and 22 sites during post-monsoon, respectively. The third one contains 8 sampling sites during pre- and only one sampling site during post-monsoon.

The mean values of chemical constituents for each cluster were shown in Table 3. It was found that Cluster 1 samples contain lowest fluoride concentration associated with slightly acidic $\mathrm{pH}$ and positive ORP value along with low $\mathrm{HCO}_{3}^{-}$concentration. Cluster 2 samples contain fluoride concentration above permissible limit associated with normal $\mathrm{pH}$, negative ORP value and moderate $\mathrm{HCO}_{3}{ }^{-}$concentration. Cluster 3 samples contain highest fluoride concentration along with alkaline $\mathrm{pH}$, highly negative ORP value and high $\mathrm{HCO}_{3}^{-}$concentration. This table once again validates the result of $\mathrm{FA}$.

Fig. 7 represents the geographical location of all sampling sites according to their clusters. The sites of Cluster 1 are mainly lying in the middle and southwestern portion of the study area, the sites of Cluster 2 lying in the southeastern portion of the study
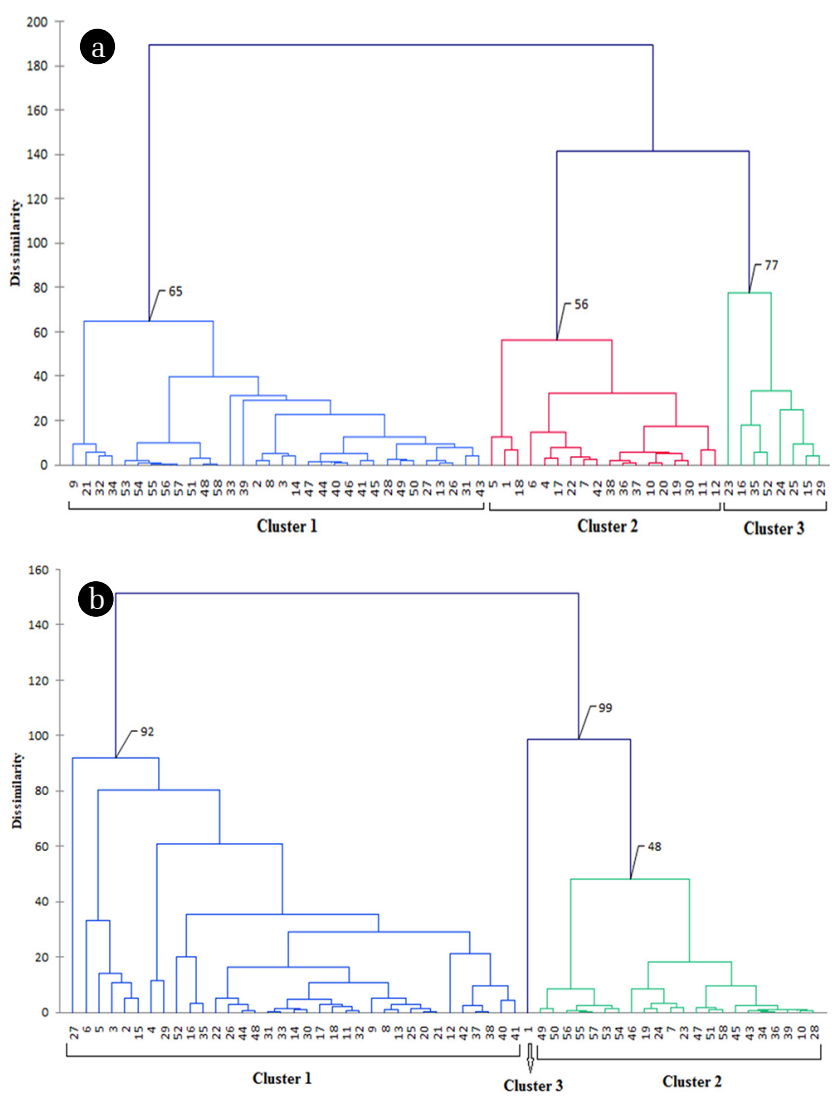

Fig. 6. Tree diagram of three clusters of groundwater quality in the study area during pre-monsoon (a) and post-monsoon (b). 
Table 3. Mean Values of the Chemical Constituent for Each Cluster

\begin{tabular}{|c|c|c|c|c|c|c|}
\hline \multirow{2}{*}{ Class } & \multicolumn{3}{|c|}{ Pre-monsoon } & \multicolumn{3}{|c|}{ Post-monsoon } \\
\hline & Cluster 1 & Cluster 2 & Cluster 3 & Cluster 1 & Cluster 2 & Cluster 3 \\
\hline $\mathrm{pH}$ & 6.46 & 6.95 & 8.69 & 6.41 & 7.02 & 9.25 \\
\hline TDS & 174.78 & 174.78 & 588.75 & 419.50 & 223.74 & 157 \\
\hline $\mathrm{EC}(\mu \mathrm{S} / \mathrm{cm})$ & 224.72 & 224.72 & 374.00 & 772.50 & 387.05 & 445 \\
\hline ORP (mV) & 4.22 & -4.22 & -40.50 & 5.42 & -1.39 & -133.11 \\
\hline $\mathrm{F}^{-}$ & 1.36 & 1.93 & 9.14 & 0.96 & 1.55 & 18.50 \\
\hline $\mathrm{Ca}^{2+}$ & 10.83 & 10.83 & 14.68 & 105.11 & 42.86 & 4.45 \\
\hline $\mathrm{Mg}^{2+}$ & 72.58 & 0.06 & 24.72 & 24.61 & 10.37 & 4.93 \\
\hline $\mathrm{Na}^{+}$ & 20.58 & 4.48 & 104.25 & 33.84 & 42.63 & 338.90 \\
\hline $\mathrm{K}^{+}$ & 1.42 & 1.933 & 3.13 & 20.92 & 2.90 & 3.70 \\
\hline $\mathrm{Cl}^{-}$ & 17.60 & 17.60 & 113.71 & 129.54 & 33.42 & 304.91 \\
\hline $\mathrm{SO}_{4}^{2-}$ & 4.48 & 20.58 & 27.21 & 18.13 & 10.70 & 8.57 \\
\hline $\mathrm{HCO}^{3-}$ & 34.39 & 1.418 & 76.59 & 18.19 & 41.30 & 68.50 \\
\hline $\mathrm{Fe}$ & 1.93 & 72.57 & 0.62 & 1.24 & 3.59 & 0.01 \\
\hline $\mathrm{Ni}$ & 0.06 & 34.38 & 0.02 & 0.04 & 0.02 & 0.02 \\
\hline $\mathrm{Zn}$ & 0.06 & 0.06 & 0.13 & 0.17 & 0.36 & 0.02 \\
\hline
\end{tabular}

Note: All the parameters are expressed as mg/L except pH, ORP, and EC.
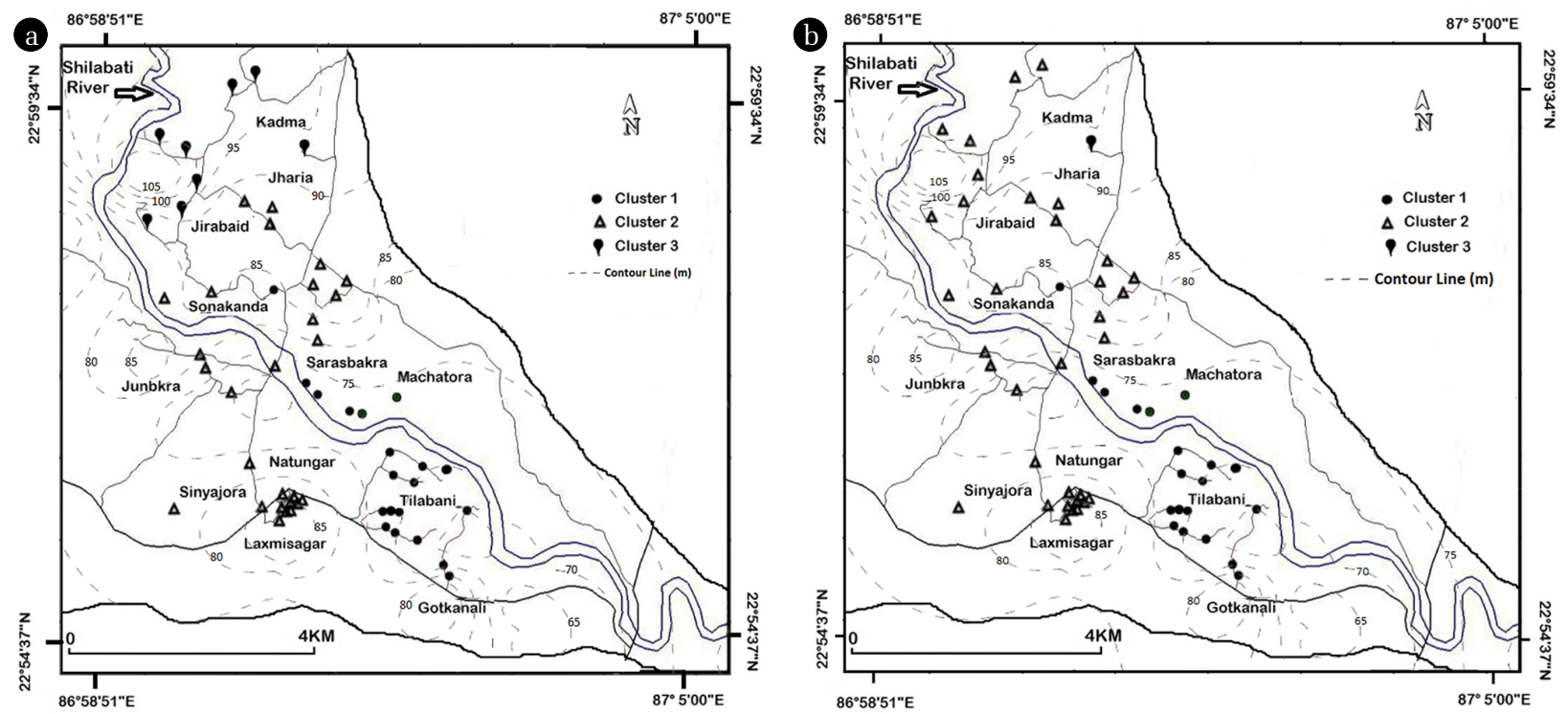

Fig. 7. Distribution of groundwater sampling sites characterized by three clusters during pre-monsoon (a) and post-monsoon (b).

area and the sites of Cluster 3 mostly appear in north and northwestern part of the study area. It was also found from the cluster analysis of sampling site that fluoride contamination was not uniform throughout the area under study and significant change in fluoride contamination was also observed during pre- and postmonsoon, respectively. Contamination level is high in the elevated region where recharging rainwater gets more contact opportunity with the minerals when it infiltrates through the vadose zone. From this elevated region, fluoride migrates to the low-lying areas and contaminates the groundwater.

\section{Conclusions}

An elevated level of fluoride concentration was found in the study area which made most of the groundwater samples unsuitable for drinking. FA of major water quality parameters revealed that fluoride contamination was strongly associated with $\mathrm{pH}$, ORP, 
and the concentration $\mathrm{HCO}_{3}{ }^{-}$and $\mathrm{Na}^{+}$ions. It was found from the study that some common geochemical process controlling the overall groundwater quality also promote the fluoride enrichment process. Among them, predominant processes were weathering and leaching of fluoride-bearing minerals, anion exchange between $\mathrm{F}^{-}$and $\mathrm{OH}^{-}$ions, evapotranspiration which concentrate the fluoride ions. From HCA, an un-uniform level of fluoride concentration was observed throughout the area under study which might be due to aquifer heterogeneity or variation in contact opportunity of the recharging rain water with the mineral during infiltration through the vadose zone.

\section{Acknowledgments}

We would like to acknowledge National Institute of Technology Durgapur for providing infrastructure. We are thankful to all faculty members, staff members and student of the Department of Earth and Environmental Studies, NIT Durgapur for the endless support. We are also thankful to the villagers, lived in the study area, for their valuable help during sampling.

\section{References}

1. Izrar AH, Yousef NZ, Faisal ZD. Groundwater pollution risk mapping using modified DRASTIC model in parts of Hail region of Saudi Arabia. Environ. Eng. Res. 2017;23:84-91.

2. Bajpayee S, Das R, Ruj B, Adhikari K, Chatterjee PK. Assessment by multivariate statistical analysis of ground water geochemical data of Bankura, India. Int. J. Environ. Sci. 2012;3:870-880.

3. Helena B, Pardo R, Vega M, Barrado E, Fernandez JM, Fernandez L. Temporal evolution of groundwater composition in an alluvial aquifer (Pisuerga river, Spain) by principal component analysis. Water Res. 2000;34:807-816.

4. Hu S, Luo T, Jing C. Principal component analysis of fluoride geochemistry of groundwater in Shanxi and Inner Mongolia, China. J. Geochem. Explor. 2013;135:124-129.

5. Ramanaiah SV, Mohan SV, Rajkumar B, Sarma PN. Monitoring of fluoride concentration in ground water of Prakasham district in India: Correlation with physico-chemical parameters. $J$. Environ. Sci. Eng. 2006;48:129-134.

6. Ayoob S, Gupta AK. Fluoride in drinking water: A review on the status and stress effects. Crit. Rev. Environ. Sci. Technol. 2006;36:433-487.

7. Guo H, Zhang Y, Xing L, Jia Y. Spatial variation in arsenic and fluoride concentrations of shallow groundwater from the town of Shahai in the Hetao basin, Inner Mongolia. Appl. Geochem. 2012;27:2187-2196.

8. Jacks G, Bhattacharya P, Chaudhary V, Singh KP. Controls on the genesis of some high-fluoride groundwaters in India. Appl. Geochem. 2005;20:221-228.

9. Biswas K, Bandhoyapadhyay D, Ghosh UC. Adsorption kinetics of fluoride on iron(III)-zirconium(IV) hybrid oxide. Adsorption 2007;13:83-94.

10. World Health Organization. Guidelines for drinking-water quality. 2004;1.

11. Reddy DV, Nagabhushanam P, Sukhija BS, Reddy AGS, Smedley PL. Fluoride dynamics in the granitic aquifer of the Wailapally watershed, Nalgonda District, India. Chem. Geol. 2010;269:278-289.

12. Fawell J, Bailey K, Chilton J, Dahi E, Fewtrell L, Magara Y. Fluoride in drinking water. IWA Publishing; 2006. p. 4-81.

13. Chakrabarti S, Bhattacharya HN. Inferring the hydro-geochemistry of fluoride contamination in Bankura district, West Bengal: A case study. J. Geol. Soc. Ind. 2013;82:379-391.

14. UNICEF. State of the art report on the extent of fluoride in drinking water and the resulting endemicity in India. New Delhi; 1999.

15. PHED Report (Public Health Engineering Department), Government of West Bengal. Activities \& achievements in rural drinking water supply and other areas [Internet]. c2007. Available from: http://www.wbphed.gov.in/applications/im/ uploads/000643.pdf.

16. Reghunath R, Murthy TS, Raghavan BR. The utility of multivariate statistical techniques in hydrogeochemical studies: An example from Karnataka, India. Water Res. 2002;36:2437-2442.

17. Park SM, Futaba KZ, Lee SH. Assessment of water quality using multivariate statistical techniques: A case study of the Nakdong River Basin, Korea. Environ. Eng. Res. 2014;19: 197-203.

18. Pazand K. Geochemistry and multivariate statistical analysis for fluoride occurrence in groundwater in the Kuhbanan basin, Central Iran. Model. Earth Syst. Environ. 2016;2:72.

19. Das N, Sarma KP, Patel AK, et al. Seasonal disparity in the co-occurrence of arsenic and fluoride in the aquifers of the Brahmaputra flood plains, Northeast India. Environ. Earth Sci. 2017;76:183.

20. Chandio TA, Khan MN, Sarwar A. Fluoride estimation and its correlation with other physicochemical parameters in drinking water of some areas of Balochistan, Pakistan. Environ. Monit. Assess. 2015;187:531.

21. American Public Health Association. Standard methods for the examination of water and wastewater. APHA; 2005.

22. McMahon PB, Chapelle FH, Bradley PM. Evolution of redox processes in groundwater. Aquat. Redox Chem. 2011;1071:581-597.

23. Champ DR, Gulens J, Jackson RE. Oxidation-reduction sequences in ground water flow systems. Can. J. Earth Sci. 1979;16:12-23.

24. Piper AM. A graphic procedure in the geochemical interpretation of water-analyses. Eos Trans. Am. Geophys. Union 1944;25:914-928.

25. Wang Y, Stepan L, Chunli S. Genesis of arsenic/fluoride-enriched soda water: A case study at Datong, Northern China. Appl. Geochem. 2009;24:641-649.

26. Gibbs RJ. Mechanisms controlling world water chemistry. Science 1970;170:1088-1090.

27. Liu CW, Cheng SJ, Chan PC, Chun NL, Kuo LL. Characterization of groundwater quality in Kinmen Island using multivariate analysis and geochemical modelling. Hydrol. Process. 2008;22:376-383.

28. Reghunath RJ, Sreedhara TR, Raghavan BR. The utility of multivariate statistical techniques in hydrogeochemical stud- 
ies: An example from Karnataka, India. Water Res. 2002;36:2437-2442.

29. Yidana SM, Duke OP, Bruce BY. A multivariate statistical analysis of surface water chemistry data - The Ankobra Basin, Ghana. J. Environ. Manage. 2008;86:80-87.

30. Adriano DC. Trace elements in the terrestrial environment. New York: Springer; 1986.

31. Guo Q, Yanxin W, Teng M, Rui M. Geochemical processes controlling the elevated fluoride concentrations in groundwaters of the Taiyuan Basin, Northern China. J. Geochem. Explor. 2007;93:1-12.

32. Singh CK, Rina K, Singh RP, Shashtri S, Kamal V, Mukherjee $\mathrm{S}$. Geochemical modeling of high fluoride concentration in groundwater of Pokhran area of Rajasthan, India. Bull. Environ. Contam. Toxicol. 2011;86:152-158.

33. Chidambaram S, Ramanathan AL, Vasudevan S. Fluoride removal studies in water using natural materials. Water $S A$ 2003;29:339-344.

34. Jacks G, Bhattacharya P, Chaudhary V, Singh KP. Controls on the genesis of some high-fluoride groundwaters in India. Appl. Geochem. 2005;20:221-228.

35. Handa BK. Geochemistry and genesis of fluoride-containing ground waters in India. Groundwater 1975;13:275-281.

36. Saxena V, Ahmed S. Dissolution of fluoride in groundwater: A water-rock interaction study. Environ. Geol. 2001;40:1084-1087. 